\title{
The Reduction of Pollution Load by Recycling Unhairing Effluent Combined with Alkali-pretreatment
}

\author{
Takuji Shirayama, Kohkichi Uehara* \\ and Hiroshi OKamura** \\ Industrial Technology Institute of Saitama, Urawa-shi 338 \\ * Tokyo Noko University, Fuchu-shi 183 \\ ${ }^{* *}$ Showa Women's University, Setagaya-ku, Tokyo 154
}

(Received March 12, 1991)

\begin{abstract}
When recycling lime-sulfide unhairing effuent, cattle hair becomes slurrylike and is very difficult to separate from the unhairing effluent. In order to easily separate hair during effluent disposal, a method was examined which provides the hair with resistivity (immunization) against sulfide. This is done by dipping hides in a calcium hydroxide solution (alkali-pretreatment) prior to unhairing which is done by recycling effluent containing sulfide. Nappa leathers were produced via the chrome tannage of wet whites obtained from pelts which were unhaired by the recycling process of unhairing effluent. The effects of the recycling process on the properties of the leather were studied. By combining the recycling process with alkali-pretreatment, the amount of sodium hydrosulfide was reduced to half the amount via the conventional process, also providing proper pelts. The water requirement was reduced by up to $75 \%$. By pretreatment with calcium hydroxide the COD load to $1 \mathrm{~kg}$ of hide was reduced by $55 \%$ of the load without the alkali-pretreatment. As a result effluent filtration was simplified so that rapid operation was allowed. The Nappa leathers produced from this unhairing process were found to have the same qualities as those produced via the conventional unhairing method.
\end{abstract}

Anim. Sci. Technol. (Jpn.) $62(10): 963-971,1991$

Key words : unhairing, sulfide, effluent-recycling, alkali pretreatment, wet white, leather

The pollutant components from tanneries are mainly contained in effluent from the beamhouse process. In order to reduce pollution, several methods have been studied, such as enzymatic unhairing methods ${ }^{2,8-12,15)}$, hair recovery methods without dissolving hair ${ }^{4-6)}$, and sulfide-free unhairing methods ${ }^{7,14,17,18)}$.

The many effluent components in the limesulfide hair burn process are difficult to remove and separate. The saving of sulfides used for unhairing is a problem to be immediately solved from the viewpoints of pollution prevention and safety improvement.

We examined an unhairing method in which effluent was reused (recycled) and replenished with the sulfide. The method was found to keep sulfide content almost constant, to provide no significant change in the swelling of pelts and to be useful for preparing properly unhaired products ${ }^{16)}$. However, effluent containing hair in a slurry-like condition, was very difficult to filter. Efforts therefore are required to make effective use of the effluent and to speed up filtration. A recent approach 
provides hair with resistivity (immunization) against sulfides via the preliminary alkali treatment of hides for preventing the dissolution of hair. Sulfides are added for unhairing after immunization ${ }^{1,3,11,13)}$.

In this paper we have applied BLAIR's unhairing method ${ }^{1)}$ for recycling the unhairing effluent, and prepared Nappa leathers from wet whites, using chrome effluent.

We estimated the effects of recycling the unhairing effluent and the saving of sulfide usage on the properties of produced leathers.

\section{Materials and Methods}

1. Raw stocks

Salt-cured steer hides imported from North America were used. The average hide weight was $28 \mathrm{~kg}$ and one lot included five hides.

2. Unhairing and preparative operations

After the hides were soaked under usual conditions, they were rotated in a drum for one hour, together with calcium hydroxide. Cattle hair, thus made immune by the alkalipretreatment, was removed by the addition of sulfide.

The amounts of chemicals added were determined on the basis of the weights of salt-cured hides for soaking and unhairing processes and on the basis of the weights of pelts for deliming, bating and subsequent processes. The speed of the drumming was set at $4 \mathrm{rpm}$ for the soaking, deliming and bating processes and at $12 \mathrm{rpm}$ for pickling and subsequent processes.

Presoaking and soaking were carried out as described in a previous paper ${ }^{16)}$.

Alkali-pretreatment: A drum containing pelts with $200 \%$ water $\left(27^{\circ} \mathrm{C}\right)$ and $1 \%$ calcium hydroxide was rotated for a total of $20 \mathrm{~min}$ and kept still for $40 \mathrm{~min}$.

The effluent from this treatment (referred to as the alkali pretreatment effluent) was used as the reliming bath solution.

Unhairing: A drum containing pelts with $200 \%$ water $\left(27^{\circ} \mathrm{C}\right)$ and $1 \%$ calcium hydroxide was rotated for $30 \mathrm{~min}$, and $2 \%$ sodium hydrosulfide was added to the mixture, rotated for $20 \mathrm{~min}$ and kept still for $40 \mathrm{~min}$. $0.5 \%$ of sodium carbonate was then added to the mixture, and the drum was rotated for $70 \mathrm{~min}$ and kept still for $140 \mathrm{~min}$.

The unhairing effluent was collected in a plastic vessel and filtered through a stainless steel screen so as to reuse it as the unhairing liquid in the unhairing process.

The amounts of sodium hydrosulfide added during the second and subsequent uses were calculated from the remaining amounts of sulfur, which were determined from the concentrations of sulfide ions, in the unhairing effluent. Replenishing calcium hydroxide was necessary to keep the degree of swelling constant, which was calculated from the ratio between weights of pelts and raw hides ${ }^{16}$. Calcium hydroxide therefore was added in the amount corresponding to $0.5 \%$ of the saltcured hide weight, in every odd-numbered recycling use. And, an appropriate amount of sodium carbonate was added to adjust the $\mathrm{pH}$ of the effluents at 12.0 .

Limed pelts were washed in the drum in flowing water for $5 \mathrm{~min}$ and weighed.

Reliming: In this process, $1 \%$ calcium hydroxide and $0.1 \%$ surface active agent were added to the effluents from the alkali pretreatment process. A drum containing the mixture was rotated for $20 \mathrm{~min}$ and then kept still for $60 \mathrm{~min}$. Afterwards, the drum was rotated for 10 min every three hours for a total of 16 hours of reliming. Since the effluents was recovered at rates of $88-93 \%$, the bath solution amount was not controlled.

3. Preparation of wet whites

The relimed pelts were washed with $200 \%$ water $\left(30^{\circ} \mathrm{C}\right)$ in a drum for $10 \mathrm{~min}$. Deliming, bating, pickling and aluminum tanning were carried out as described in a previous paper ${ }^{16)}$.

After 2 hours of horsing up, the grain side of the wet whites were shaved to a thickness of $0.8 \mathrm{~mm}$. Then, they were weighed. 


\section{Recycle of Unhairing Effluent Combined with Alkali-pretreatment}

4. Preparation of Nappa leathers from wet whites

The wet whites were washed with flowing water for $10 \mathrm{~min}$ to remove shaving dust, $150 \%$ water and $10 \%$ sodium chloride (on the basis of the shaved whites weight) were added to the mixture in the drum. After $10 \mathrm{~min}$ of drumming, $1 \%$ sulfuric acid and 1\% formic acid were added and the mixture in the drum was rotated for 2 hours. The drum was rotated for $10 \mathrm{~min}$ every 3 hours and followed for 16 hours. After 4 hours of horsing up, the wet whites were subjected to chrome tannage operations under the following conditions. In ead successive tannage operations after the first, we made recycling use of the effluents from the tannage process.

First chrome tanning: A drum containing the wet whites was rotated with $60 \%$ water and $2 \%$ sodium chloride for $10 \mathrm{~min}$. $6 \%$ of chrome tanning agent $\left(\mathrm{Cr}_{2} \mathrm{O}_{3}: 25 \%\right.$, Chromosal $\mathrm{B}$, Bayer) was added to the mixture which was rotated for 1 hour. Another $0.8 \%$ of sodium bicarbonate was added to the mixture, which was rotated for 5 hours. An appropriate amount of sodium bicarbonate was added to adjust the final $\mathrm{pH}$ of the float at 3.8 and the mixture was kept still for 16 hours. The chrome-tanned leathers were horsed up for 24 hours.

Chrome recycling: A drum containing wet whites was rotated with $60 \%$ water (chrome tanning effluent) and $0.5 \%$ formic acid for 10 min. Then, X\% of chrome tanning agent (X value was calculated from the residual chrome content of chrome tanning effluent) was added and the mixture rotated for 1 hour. Then, an appropriate amount of sodium bicarbonate was added to adjust the final $\mathrm{pH}$ of the float at 3.8 and the mixture was kept still for 16 hours. The chrome-tanned leathers were horsed up for 24 hours. Washing: The leathers were washed in a drum with $200 \%$ water $\left(40^{\circ} \mathrm{C}\right)$ and $1 \%$ formic acid for $10 \mathrm{~min}$.

Retannage, dyeing and fatliquoring were made under the following conditions. The amounts of chemicals added were based on the weight of the shaved wet whites.

Retanning, neutralization and dyeing: A drum containing the chrometanned leathers was rotated with $150 \%$ water $\left(40^{\circ} \mathrm{C}\right)$ and $3 \%$ glutaraldehyde (Relugan GT 50, BASF) for $30 \mathrm{~min}$, and then $2 \%$ synthetic tannin (Tanigan PC, Bayer), $0.3 \%$ sodium bicarbonate, $1.2 \%$ dyestuff (Coranil dark brown HEB, Hoechst), $1.6 \%$ dyestuff (Coranil brown HEGB, Hoechst), $2 \%$ fatliquoring agent (Chromopol UFS, Stockhausen), $1 \%$ fatliquoring agent (Tetrapol SAF, Stockhausen), $4 \%$ mimosa, $4 \%$ synthetic tannin (Tanigan BN, Bayer) and $2 \%$ synthetic tannin (Retingan R 7, Bayer) were added successively to the mixture. The drum was rotated continuously for 2.5 hours. After $200 \%$ water $\left(50^{\circ} \mathrm{C}\right)$ was added, the drum was rotated for $10 \mathrm{~min}$. A drum containing the leathers was rotated with $150 \%$ water $\left(50^{\circ} \mathrm{C}\right), 0.6 \%$ dyestuff (Coranil dark brown HEB, Hoechst) for $20 \mathrm{~min}$, and then $3.5 \%$ fatliquoring agent (Coripol BZN, Stockhausen), $4.5 \%$ fatliquoring agent (Coripol DX-W, Stockhausen), 4.5\% fatliquoring agent (Chromopol UFS, Stockhausen) and $1 \%$ formic acid were added successively to the mixture and the drum was rotated continuously for $50 \mathrm{~min}$. The $\mathrm{pH}$ at the end was 3.8 . The leathers were washed in the drum with flowing water for $5 \mathrm{~min}$ and were horsed up for 16 hours.

The leathers were finished by conventional polishing with felt buffs.

5. Analyses and tests

1) Analyses of unhairing effluents and wet whites

The effuent, of the unhairing process was filtered through a 60 -mesh screen and samples for analyses were taken. Transparency, $\mathrm{pH}$, total evaporation residue, ignition residue, total nitrogen, volatile nitrogen and COD were measured via methods used for testing plant waste solutions (JIS K 0102).

Sulfur ions were measured by an ion meter 
(Type 801, sulfide ion electrode: Type 94-16, reference electrode : Type 90-02).

Chemical analyses in accordance with JIS $K$ 6550 were made of $7 \times 7 \mathrm{~cm}$ samples taken from the butt parts of wet whites. The aluminum contents of wet whites were measured by atomic absorption spectroscopy ${ }^{16}$.

2) Properties of leathers

Chrome tanned wet whites and leathers were subjected to the following chemical analyses, physical tests and sensory evaluations.

Chemical analyses: Measurements were made of the contents of moisture, total ash, fat, hide substance, soluble component, soluble ash and chromium, as well as the $\mathrm{pH}$ and $\mathrm{Ts}$, in accordance with JIS K 6550 .

The aluminum contents of leather were measured by atomic absorption spectroscopy ${ }^{16}$.

Physical properties: The thickness, tensile strength, elongation at break and tear strength were measured in accordance with JIS K 6550 . Stiff ness was measured by the Gurley method. The apparent densities were calculated as the weights per volumes.

Sensory tests: The leathers prepared from wet blues by use of $6 \%$ chrome tanning agents, were regarded as standards. Sensory tests were made of the softness, smoothness, break, fineness and dyeability, via a 5 point evaluation system. The evaluation values were denoted by the averages of the values given by three inspectors.

The area of leather was measured with an optical leather area meter.

\section{Results and Discussion}

1. Properties of pelts and compositions of effluents in the unhairing process

When recycling effluent with added sulfide, it was very difficult to filtrate the effluent because of the slurry of cattle hair. BLAIR's method was therefore applied to improve the efficiency of filtration of the unhairing effluent. Hides are dipped in a solution of calcium hydroxide to provide hair with immunity against sulfide and to prevent the hair dissolving. In this applied method, the unhairing process was divided into the pre-unhairing (alkali-pretreatment) and unhairing processes.

The effluent of the pre-unhairing process was used directly in the reliming bath, while the effluent of the unhairing process was filtered for repeated use.

According to this method, cattle hair decomposes to form slurry as in the conventional method but filtration of the effluent is easy, facilitating effective use of the effluent and reducing the time of operation.

Tables 1 and 2 show the degree of swelling and properties of pelts prepared in the circulated effuent, and the composition of the effluent, respectively.

The degree of swelling of the pelts decreased at the second circulation, after which there was no significant change in level.

The compositional changes in the unhairing effluent are indicated by the ratios of component content between the first and tenth

Table 1. Degree of swelling and appearance inspection of pelts made by recycling process of unhairing effluents

\begin{tabular}{lccccccccccccc}
\hline & \multicolumn{1}{c}{ Recycling number of unhairing effluents } & \multicolumn{3}{c}{ Total } \\
Measured items & 1 & 2 & 3 & 4 & 5 & 6 & 7 & 8 & 9 & 10 & (Average) \\
\hline Hide weight $(\mathrm{kg})$ & 140.7 & 142.3 & 142.8 & 141 & 5 & 144.8 & 144.2 & 143.6 & 141.2 & 142.4 & 144.2 & 1427.7 \\
Pelt weight $(\mathrm{kg})$ & 203.0 & 183.6 & 194.2 & 200.9 & 202.9 & 198.9 & 204.0 & 198.7 & 198.2 & 204.7 & 1989.1 \\
Degree of swelling & 1.44 & 1.29 & 1.36 & 1.42 & 1.40 & 1.38 & 1.42 & 1.41 & 1.39 & 1.42 & $(1.39)$ \\
Appearance inspection & $\mathrm{N}$ & $\mathrm{H}$ & $\mathrm{N}$ & $\mathrm{N}$ & $\mathrm{N}$ & $\mathrm{H}$ & $\mathrm{N}$ & $\mathrm{N}$ & $\mathrm{N}$ & $\mathrm{N}$ & $\mathrm{N}$ \\
\hline
\end{tabular}

Degree of swelling: Pelt weight/Hide weight,

Appearance inspection; $\mathrm{N}$ : Normal, $\mathrm{H}$ : Hair remained in a hide 
circulations. The quantities of all the compositions increased as follows.

The ratios were 1.36 for the total evaporation residue, 1.49 for the incineration residue of the evaporation remains, 2.29 for the total nitrogen, 2.01 for the volatile nitrogen and 1.54 for COD. The total and volatile nitrogen contents, significantly increased. This is considered due to the accumulation of proteins, fats and other organic substances in the effluent, due to their dissolution and decomposition by sulfide and lime.

The COD load to $1 \mathrm{~kg}$ of hide was $51.6 \mathrm{~g}$ in comparison with the load of $113.8 \mathrm{~g}^{16)}$ in the case without pretreatment; the reduction was $55 \%$. This indicates that the hair in the slurry was effectively filtered out. As a result filtration of the effluent was simplified so that rapid operation was allowed.

The amount of sulfides remaining in the effluents was $56 \%$ of the added sulfide amount.

By recycling unhairing effluent the water requirement was a more 702 liters in comparison with the 2,854 liters needed when not recycling effluent. The water requirement can be reduced by $75 \%$.

Table 2. Analysis of unhairing effluents after depilation

\begin{tabular}{|c|c|c|c|c|c|c|c|c|c|c|c|}
\hline \multirow[b]{2}{*}{ Measured items } & \multicolumn{10}{|c|}{ Recycling number of unhairing effluents } & \multirow[b]{2}{*}{ Average* } \\
\hline & 1 & 2 & 3 & 4 & 5 & 6 & 7 & 8 & 9 & 10 & \\
\hline Transparency $(\mathrm{cm})$ & 0.5 & 0.5 & .5 & 0.5 & 0.5 & $0.5<$ & $0.5<$ & $<0.5<$ & $<0.5<$ & $<0.5$ & \\
\hline pH & 12.4 & 12.4 & 12.6 & 12.6 & 12.6 & 12.8 & 12.6 & 12.6 & 12.8 & 12.8 & \pm 0.1 \\
\hline ation residues & 20580 & 21265 & 22460 & 22565 & 23940 & 24095 & 25145 & 26366 & 25270 & 28045 & \\
\hline Ignition residues (mg/l) & 11798 & 12425 & 13520 & 13075 & 14520 & 15466 & 16205 & 16870 & 17655 & 17587 & $14912 \pm 2045$ \\
\hline Total nitrogen ( $\mathrm{mg} / \mathrm{l})$ & 1145 & 1246 & 1320 & 1455 & 1682 & 1725 & 1982 & 2215 & 2460 & 2619 & $1785 \pm 491$ \\
\hline Volatile nitrogen $(\mathrm{mg} / l)$ & 92 & 114 & 136 & 153 & 138 & 159 & 166 & 156 & 164 & 185 & $146 \pm 26$ \\
\hline $\mathrm{COD}(\mathrm{mg} / \mathrm{l})$ & 19820 & 21080 & 23565 & 24226 & 26810 & 26305 & 28905 & 28814 & 37880 & 30615 & $25802+3362$ \\
\hline $\begin{array}{l}\mathrm{S}^{--} \text {of initial liquor } \\
(\mathrm{mg} / \mathrm{l})\end{array}$ & 3452 & 3645 & 3544 & 3470 & 3546 & 3485 & 3440 & 3505 & 3424 & 3471 & $3498 \pm 62$ \\
\hline $\mathrm{S}^{--}$of effuent $(\mathrm{mg} / \mathrm{l})$ & 2088 & 1988 & 1973 & 1956 & 1933 & 2021 & 1954 & 1988 & 1905 & 1910 & $1972 \pm 52$ \\
\hline Residual $\mathrm{S}^{--(\%)}$ & 60.5 & 54.5 & 55.7 & 56.4 & 54.5 & 58.0 & 56.8 & 56.7 & 55.6 & 55.0 & $56.4 \pm 1.7$ \\
\hline
\end{tabular}

* : Mean value \pm standard deviation

Table 3. Amount of calculated or offered chemical agents in the recycling process of unhairing effluents

\begin{tabular}{|c|c|c|c|c|c|c|c|c|c|c|c|c|}
\hline & & \multicolumn{11}{|c|}{ Recycling number of unhairing efluents } \\
\hline & & 1 & 2 & 3 & 4 & 5 & 6 & 7 & 8 & 9 & 10 & Total \\
\hline \multicolumn{13}{|c|}{ Calculated amount $\left(\mathrm{kg}^{*}\right)^{*}$} \\
\hline & $\mathrm{Ca}(\mathrm{OH})_{2}$ & 1.41 & 1.42 & 1.43 & 1.42 & 1.45 & 1.44 & 1.44 & 1.41 & 1.42 & 1.44 & 14.28 \\
\hline & $\mathrm{NaSH}$ & 2.82 & 2.84 & 2.86 & 2.84 & 2.90 & 2.88 & 2.88 & 2.82 & 2.84 & 2.88 & 28.56 \\
\hline & $\mathrm{NaCO}_{3}$ & 0.71 & 0.71 & 0.72 & 0.71 & 0.73 & 0.72 & 0.72 & 0.72 & 0.72 & 0.72 & 7.18 \\
\hline & Float $(l)$ & 281 & 283 & 286 & 284 & 290 & 288 & 288 & 282 & 284 & 288 & 2854 \\
\hline \multicolumn{13}{|c|}{ Offered amount $\mathrm{k}$} \\
\hline & $\mathrm{Ca}(\mathrm{OH})_{2}$ & 1.41 & - & 0.72 & - & 0.72 & - & 0.72 & $\cdots$ & 0.72 & - & 4.29 \\
\hline & $\mathrm{NaSH}$ & 2.82 & 1.12 & 1.30 & 1.26 & 1.26 & 1.31 & 1.21 & 1.22 & 1.23 & 1.28 & 14,01 \\
\hline & $\mathrm{NaCO}_{3}$ & 0.71 & 0.2 & - & 0.2 & - & 0.3 & - & - & 0.2 & - & 1.41 \\
\hline & Float (l) & 281 & 45 & 49 & 39 & 51 & 50 & 54 & 40 & 48 & 45 & 702 \\
\hline
\end{tabular}

*: In the case of not recycling process, this amount is calculated by hide weight 


\section{Shirayama, Uehara and OKamura}

Table 3 shows the amounts of chemicals added to recycling effluents for unhairing. The amount of sodium hydrosulfide added in ten times of circulation was $49 \%$ of the amount added in the conventional process. This indicates that the proper preparation of pelts can be made by using $50 \%$ of the conventionally required amount of sodium hydrosulfide. Thus, recycling effluent was found to be very effective in reducing sulfide content.

2. Properties of wet whites

Table 4 shows the chemical analysis values of wet whites prepared from pelts by recycling unhairing effluent.

The average values of individual components at the tenth recycling use were as follows.

Moisture : $66.1 \%$, total ash : $8.56 \%$, fats : $3.61 \%$, hide substance: $85.3 \%$, aluminum : $4.19 \%, \mathrm{pH}: 3.53$, and $\mathrm{Ts}: 76.7^{\circ} \mathrm{C}$. The properties of the wet whites were not significantly changed, as indicated from the comparison with the data which was obtained from the wet white (control sample) prepared with no use of the unhairing effluent.

Table 4. Analysis of wet white produced from the pelt unhaired by recycling process of unhairing effluents

\begin{tabular}{|c|c|c|c|c|c|c|c|c|c|c|c|}
\hline \multirow{2}{*}{$\begin{array}{l}\text { Measured } \\
\text { items }\end{array}$} & \multicolumn{10}{|c|}{ Recycling number of unhairing effluents } & \multirow[b]{2}{*}{ Average* } \\
\hline & 1 & 2 & 3 & 4 & 5 & 6 & 7 & 8 & 9 & 10 & \\
\hline Moisture & 67.5 & 65.5 & 56.5 & 64.3 & 68.3 & 62.4 & 65.5 & 67.4 & 66.2 & 67.7 & $66.1 \pm 1.70$ \\
\hline Total ash & 8.81 & 8.54 & 8.73 & 8.14 & 8.37 & 8.97 & 9.14 & 7.96 & 8.25 & 8.73 & $8.56 \pm 0.36$ \\
\hline Fat & 3.26 & 4.11 & 3.47 & 3.07 & 2.92 & 4.08 & 3.65 & 3.66 & 3.83 & 4.07 & $3.61 \pm 0.41$ \\
\hline Hide substance & 84.9 & 84.3 & 87.0 & 84.8 & 85.1 & 84.7 & 86.1 & 85.6 & 84.7 & 86.2 & $85.3 \pm 0.81$ \\
\hline $\mathrm{Al}_{2} \mathrm{O}_{3}$ & 4.46 & 3.87 & 3.71 & 3.92 & 4.29 & 4.57 & 4.36 & 3.98 & 4.25 & 4.52 & $4.19 \pm 0.29$ \\
\hline $\mathrm{pH}$ & 3.50 & 3.47 & 3.60 & 3.44 & 3.52 & 3.61 & 3.48 & 3.70 & 3.52 & 3.50 & $3.53 \pm 0.07$ \\
\hline $\mathrm{Ts}\left({ }^{\circ} \mathrm{C}\right)$ & 75.6 & 78.6 & 76.2 & 77.0 & 78.4 & 76.2 & 75.5 & 76.6 & 77.2 & 75.8 & $76.7 \pm 1.0$ \\
\hline
\end{tabular}

Moisture: based on the sample weight, (\%)

Total ash, fat, hide substance, $\mathrm{Al}_{2} \mathrm{O}_{3}$ : based on the dry weight basis, (\%)

*: Mean value \pm standard deviation

Table 5. Amount of offered chrome tanning agents and weight of wet white produced from the pelt unhaired by recycling process of unhairing effluents

\begin{tabular}{|c|c|c|c|c|c|c|c|c|c|c|c|}
\hline \multirow[b]{2}{*}{ Measured items } & \multicolumn{10}{|c|}{ Recycling number of unhairing effluents } & \multirow[b]{2}{*}{ Total (Ave. ${ }^{*}$ ) } \\
\hline & 1 & 2 & 3 & 4 & 5 & 6 & 7 & 8 & 9 & 10 & \\
\hline $\begin{array}{l}\text { Total weight of } \\
\text { wet white }(\mathrm{kg})\end{array}$ & 86.2 & 89.6 & 90.2 & 86.5 & 88.2 & 89.8 & 88.3 & 87.1 & 88.6 & 90.3 & 884.8 \\
\hline $\begin{array}{l}\text { Grain side weight } \\
\text { of wet white }(\mathrm{kg})\end{array}$ & 34.2 & 33.6 & 36.4 & 32.8 & 33.7 & 35.2 & 33.8 & 34.4 & 32.5 & 34.5 & 341.5 \\
\hline $\begin{array}{l}\text { Grain side weight } \\
\text { of wet white after } \\
\text { shaving }(\mathrm{kg})\end{array}$ & 22.7 & 24.8 & 24.7 & 25.5 & 23.8 & 24.3 & 24.2 & 23.9 & 24.2 & 23.4 & 241.5 \\
\hline $\begin{array}{l}\text { Calculated chrome } \\
\text { tanning agents }(\mathrm{kg})\end{array}$ & 1.36 & 1.48 & 1.48 & 1,53 & 1.43 & 1.46 & 1.45 & 1.43 & 1.45 & 1.39 & 14.46 \\
\hline $\begin{array}{l}\text { Residual chrome in } \\
\text { tan. effuent }(\mathscr{6})\end{array}$ & 26.3 & 27.2 & 24.7 & 23.8 & 25.5 & 22.9 & 25.2 & 27.1 & 25.6 & 26.4 & $(25.5 \pm 1.3)$ \\
\hline $\begin{array}{l}\text { Offored chrome } \\
\text { tanning agents }(\mathrm{kg})\end{array}$ & 1.36 & 1.12 & 1.08 & 1.16 & 1.07 & 1.10 & 1.12 & 1.06 & 1.06 & 1.02 & 11.15 \\
\hline $\begin{array}{l}\text { Weight of wet white } \\
\text { split }\end{array}$ & 34.3 & 32.2 & 31.2 & 32.5 & 31.8 & 30.9 & 28.6 & 28.9 & 30.5 & 29.4 & 310.3 \\
\hline
\end{tabular}

Mean valuetstandard deviation 
Recycle of Unhairing Effluent Combined with Alkali-pretreatment

3. Yields of wet whites and amounts of chrome tanning agents used

Table 5 shows the yields of wet whites produced from recycling the unhairing process.

The following shows the amounts of chrome agents required in the chrome retanning of wet whites and in the direct chrome tanning of pelts, as obtained from the data in Table 5.

(1) Total weight of wet white $\cdots \cdots .884 .8 \mathrm{~kg}$

(2) Grain side weight of wet white $\cdots \cdots 341.5$ $\mathrm{kg}(38.6 \%$ of total weight)
(3) Grain side weight of wet white after shaving $\cdots \cdots \cdot 241.5 \mathrm{~kg}$

(4) Offered chrome tanning agents $6 \%$ on shaved whites (3)) $\cdots \cdots \cdot 14.5 \mathrm{~kg}$

(5) Pelt weight of grain side wet white $\cdots . .$. $767.8 \mathrm{~kg}(1989.1 \times 0.386$, converted from Table 1)

(6) Offered chrome tanning agents (6\% on pelt weight (5)) $\cdots \cdots 46.1 \mathrm{~kg}$

In the case of the chrome retannage of wet whites, the amount of chrome agents added ( 6

Table 6. Analysis of nappa leather produced from the pelt unhaired by recycling process of unhairing effuents

\begin{tabular}{lcccccccccccc}
\hline \hline & \multicolumn{10}{c}{ Recycling number of unhairing effluents } \\
Measured items & 1 & 2 & 3 & 4 & 5 & 6 & 7 & 8 & 9 & 10 & Average* $^{*}$ \\
\hline Moisture & 18.3 & 19.0 & 18.3 & 19.4 & 19.2 & 18.1 & 18.8 & 19.1 & 18.6 & 19.1 & $18.8 \pm 0.42$ \\
Total ash & 5.78 & 6.20 & 5.51 & 6.41 & 5.39 & 5.76 & 5.64 & 6.13 & 5.60 & 6.11 & $5.85 \pm 0.32$ \\
Fat & 5.23 & 5.47 & 5.72 & 5.04 & 5.57 & 5.11 & 5.32 & 5.36 & 5.17 & 5.80 & $5.38 \pm 0.24$ \\
Hide substance & 78.0 & 79.1 & 78.3 & 78.1 & 79.1 & 78.3 & 78.8 & 79.4 & 79.6 & 78.2 & $78.7 \pm 0.55$ \\
Soluble component & 0.77 & 0.68 & 0.94 & 0.68 & 0.75 & 0.79 & 0.84 & 0.86 & 0.73 & 0.68 & $0.78 \pm 0.08$ \\
Soluble ash & 0.12 & 0.09 & 0.13 & 0.11 & 0.08 & 0.09 & 0.14 & 0.07 & 0.16 & 0.13 & $0.11 \pm 0.03$ \\
$\mathrm{Cr}_{2} \mathrm{O}_{3}$ content & 3.41 & 3.27 & 3.62 & 3.25 & 3.29 & 3.30 & 3.18 & 3.28 & 3.22 & 3.45 & $3.33 \pm 0.12$ \\
$\mathrm{Al}_{2} \mathrm{O}_{3}$ content & 1.04 & 0.89 & 1.07 & 0.94 & 1.10 & 0.84 & 1.05 & 0.97 & 0.95 & 0.87 & $0.97 \pm 0.10$ \\
$\mathrm{pH}$ & 3.59 & 3.62 & 3.66 & 3.54 & 3.62 & 3.58 & 3.54 & 3.65 & 3.55 & 3.60 & $3.60 \pm 0.04$ \\
$\mathrm{Ts}\left({ }^{\circ} \mathrm{C}\right)$ & 98 & 98 & 97 & 98 & 98 & 98 & 98 & 97 & 98 & 97 & $98 \pm 0.5$ \\
\hline
\end{tabular}

Moisture : based on the sample weight, $(\$ 6)$

Total ash, fat, hide substance, soluble component, soluble ash, $\mathrm{Cr}_{2} \mathrm{O}_{3}$ content, $\mathrm{Al}_{2} \mathrm{O}_{3}$ content: based on the dry weight basis, (\%)

* : Mean valuetstandard deviation

Table 7. Characteristics of nappa leather produced from the pelt unhaired by recycling process of unhairing effluents

\begin{tabular}{|c|c|c|c|c|c|c|c|c|c|c|c|}
\hline \multirow[b]{2}{*}{ Measured items } & \multicolumn{10}{|c|}{ Recycling number of unhairing effuents } & \multirow[b]{2}{*}{ Average* } \\
\hline & 1 & 2 & 3 & 4 & 5 & 6 & 7 & 8 & 9 & 10 & \\
\hline Thickness (mm) & 0.98 & 1.02 & 0.99 & 1.04 & 1.01 & 0.94 & 1.02 & 1.01 & 0.98 & 1.02 & $1.00 \pm 0.03$ \\
\hline $\begin{array}{l}\text { Tensile strength } \\
\left(\mathrm{kgf} / \mathrm{mm}^{2}\right)\end{array}$ & 1.09 & 0.97 & 0.95 & 0.98 & 0.96 & 1.02 & 0.97 & 0.84 & 0.91 & 0.98 & $0.97 \pm 0.06$ \\
\hline $\begin{array}{l}\text { Elongation at break } \\
(\mathscr{\%})\end{array}$ & 64.2 & 62.5 & 59.5 & 61.7 & 62.2 & 61.3 & 67.2 & 58.4 & 61.5 & 64.3 & $62.3 \pm 2.4$ \\
\hline Tear strength $(\mathrm{kgf} / \mathrm{mm})$ & 2.03 & 1.98 & 2,11 & 1.94 & 2.02 & 1.95 & 2.21 & 1.93 & 2.07 & 2.18 & $2.04 \pm 0.09$ \\
\hline Stiffness (mgf) & 327 & 416 & 320 & 339 & 426 & 403 & 419 & 377 & 341 & 401 & $377 \pm 39$ \\
\hline $\begin{array}{l}\text { Appatent density } \\
\left(\mathrm{g} / \mathrm{cm}^{3}\right)\end{array}$ & 0.554 & 0.601 & 0.573 & 0.582 & 0.605 & 0.597 & 0.603 & 0.565 & 0.583 & 0.584 & $0.583 \pm 0.016$ \\
\hline Yield in areas (DS) & 232 & 218 & 226 & 207 & 221 & 230 & 227 & 219 & 230 & 220 & $223 \pm 7$ \\
\hline
\end{tabular}

* : Mean value \pm standard deviation 


\section{SHIRAYAma, UEHaRA and OKamURA}

Table 8. Appearance evaluation of nappa leather produced from the pelt unhaired by recycling process of unhairing effuents

\begin{tabular}{lcccccccccccc}
\hline & \multicolumn{10}{c}{ Recycling } \\
\hline Measured items & 1 & 2 & 3 & 4 & 5 & 6 & 7 & 8 & 9 & 10 & Average \\
\hline Softness & 3.0 & 3.6 & 3.2 & 3.2 & 3.4 & 3.4 & 4.0 & 3.6 & 3.4 & 3.4 & 3.4 \\
Smoothness & 2.8 & 3.0 & 3.0 & 3.0 & 3.0 & 3.2 & 2.8 & 3.0 & 3.2 & 3.0 & 3.0 & of unhairing effluents \\
Break & 2.8 & 2.8 & 3.0 & 2.8 & 2.6 & 2.8 & 3.0 & 2.8 & 2.8 & 3.0 & 2.8 \\
Fineness & 3.0 & 3.2 & 3.2 & 3.2 & 3.0 & 3.2 & 3.2 & 3.0 & 3.0 & 3.2 & 3.1 \\
Dyeability & 3.0 & 3.0 & 3.0 & 3.0 & 3.0 & 2.6 & 3.0 & 3.2 & 3.2 & 3.2 & 3.0 \\
\hline
\end{tabular}

Standard: Nappa leather produced from wet blue ( $6 \%$ chrome tanning agents)

Poor: 1 , same as standard : 3 , good : 5

$\%$ to shaved whites) was $14.5 \mathrm{~kg}$. The amount of chrome tanning agents ( $6 \%$ on pelt weight) used were $46.1 \mathrm{~kg}$ in the case of without preparation of wet white. The reduction of chrome tanning agents was $70 \%$.

The total amount of chrome agent used $11.15 \mathrm{~kg}$. Since the chrome tanning effluents were recycled in the chrome retanning process, the reduction of chrome agent was $80 \%$.

4. Properties of Nappa leathers

Tables 6,7 and 8 show the chemical analysis data, the physical properties and the sensory test results of the produced Nappa leathers, respectively.

The chemical analysis results are as follows. Total ash : $5.85 \%$, fat : $5.38 \%$, hide substance : $78.7 \%$, soluble component : $0.78 \%$, soluble ash : $0.1 \%$, chromium : $3.33 \%$, aluminum : $0.97 \%$, $\mathrm{pH}: 3.60$ and Ts : $98^{\circ} \mathrm{C}$. No significant changes were observed in chemical analysis values of the leathers prepared by recycling unhairing effluent.

The following figures are the ratios of physical properties of produced leathers (see Table 7) prepared in the first and tenth circulations of the effluents. The ratio was 1.04 for thickness, 0.90 for tensile strength, 1.07 for tearing strength, 1.0 for clongation at break, 1.23 for stiffness, 1.05 for apparent density and 0.95 for area yield. Thus, no significant changes were recognized for recycling effluent.

According to the sensory tests of the produced leathers (Table 8 ), the recycling use of the effluent slightly increased the softness and slightly decreased the level of break. However, no significant changes were found in comparison with the standard products.

From the above-mentioned results, Nappa leathers can be properly produced by recycling effuents from the unhairing process with alkali-pretreatment.

\section{References}

1) Blair, T.C., The Blair hair system, Leather Manufacturer, 11 : No. 12. 18. 1986.

2) Chandraekaran, S. and S.C. Dhar, Studies on the development of a multiple proteinase concentrate and its application in the depilation of skins, Leather Sci., 32 : 297-304. 1985.

3) Christner, J., The pros and cons of a hair-save process in the beamhouse, J. Am. Leather Chem. Assoc., $83: 183-192$. 1988.

4) Cranston, R.W., M.H. Davis and J.G. SCroggre, Further report on the new CSIRO unhairing process, J.G., Das Leder, 35 : 55-59. 1984.

5) Cranston, R.W., M.H. Davis and J.G. SCROGGIE, Practical considerations on the SIROLIME process, J. Soc. Leather Tech. Chem., $70: 50-55.1986$.

6) Cranston, R.W., M.H. Davis and J.G. SCROGGIE, A possible modification of the "Sirolime" hair-recovery process for rapid production of "Wet-Blue" leather, Das Leder, 37: 204-208. 1986.

7) Elsinger, F., K.H. Munz, R. BabineK and V. OLIP, Sulfidefreies Enthaarungsund Hautaufschlußverfahren, Das Leder, 38: 143-146. 1987.

8) Felicjaniak, B., Studies on enzymatic 
unhairing : part I. The influence of pigskin alkalisation on the destruction of skin grain during depilation with pancreatic enzymes, J. Soc. Leather Tech. Chem., 69 : 160-163. 1985.

9) Felicjantak, B., Studies on enzymatic unhairing: part II. The influence of alkalisation on the destruction of the grain of pigskins depilated with a bacterial enzymatic preparation, J. Soc. Leather Tech. Chem., 69: 164-165. 1985.

10) Felicjaniak, B., Studies on enzymatic dehairing: part III. Enzymatic depilation of pigskins modified by alkalisation, J. Soc. Leather Tech. Chem., 70: 14-17. 1986.

11) Felicjaniak, B., Studies on enzymatic dehairing : part IV. Methods of preparing calf skins for enzymatic depilation, J. Soc. Leather Tech. Chem., 70: 17-18. 1986.

12) Jonczyk, W. and K. Studniarski, Enzyme Unhairing of Pigskins, J. Soc. Leather Tech. Chem., 72: 83-88. 1988.
13) Mason, I.G., A hair recovery process for hides, J. Soc. Leather Tech. Chem., 68: 93-101. 1984.

14) Müller, L., Sulfidfreies Enthaaren schlchtfrischer Häute, Das Leder, 38 : 135-138. 1987.

15) Pilawski, S. and B. Felicjaniak, Die Einwirkung von Pankreasenzymen aufchweinshäute im EnthaarungsprozeB, Das Leder, 27 : 102-109. 1976.

16) Shirayama, T., K. Uehara and H. OKaMURA, The saving of sulfide by recycling unhairing effluents and the preparation of soft upper leather, Anim. Sci. Technol. (Jpn.), 62: 169-177. 1991.

17) Smidek, J. and E. Heidemann, Entwicklung von sulfidfreien und sulfidarmen Enthaarungen, Das Leder, 38 : 48-57. 1987.

18) Thorstensen, T.C. and C. Dubost, Studies on chemical unhairing systems, J.A.L.C. A., $80: 47-53.1985$.

\title{
アルカリ前好理を併用した脱毛排液の循環による 污濁負荷の削減
}

\author{
白山琢持・上原孝吉* 岡村 浩** \\ 埼玉県工業技術研究所, 浦和市 338 \\ *東京農工大学，付中市 183 \\ ** 昭和女子大学, 東京都世田谷区 157
}

\begin{abstract}
原料皮の脱毛石灰漬排液に硫化物を添加し循環利用を行なう場合，排液中の毛がスラリー状上なり排 液のろ過が著しく困難である，そこで，原料皮を水酸化カルシゥム溶液で前処理し，毛に硫化物に対す る抵抗性（免没）在付与した後，脱毛石灰漬排液の㽞環利用による脱毛石灰漬を行なった。脱毛石灰漬 排液の循環利用で調製した裸皮からウエットホワイトを経て，クロム䩮しによりナッパ革を製造し，脱 毛石灰漬排液の循環利用が製品革の性状に及ぼす影㗽を検討した。

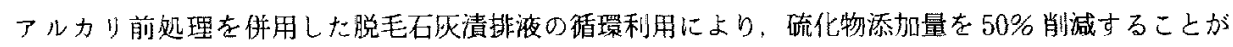
でき，しかる正常な裸皮を調製することができた，水の使用量は $75 \%$ 削減可能であった。

アルカリ前赺理により原料皮 $1 \mathrm{~kg}$ に対する $\mathrm{COD}$ 負荷量は $55 \%$ 削減され，排液のろ別が容易にな り作業の迅速化が図られた。

脱毛石灰清排液の循環利用で調制した裸皮からウエットホワイトを経て，クロム鞦しにより品質を損 なうことなくナッパ革の製造が可能であった。
\end{abstract}

日畜会報，62(10)：963-971，1991 